\title{
A Morphological, Histological and Histochemical Study of the Sexual Segment of the Kidney of the Male Chamaeleo calyptratus (Veiled Chameleon)
}

\author{
Un Estudio Morfológico, Histológico e Histoquímico del Segmento Sexual \\ del Riñón del Macho Chamaeleo calyptratus (Camaleón Velado)
}

Mohammed Ali Al-shehri' ${ }^{1}$ \& Amin Abdullah Al-Doaiss ${ }^{1,2}$

AL-SHEHRI, M.A. \& AL-DOAISS, A. A. A morphological, histological, and histochemical study of the sexual segment of the kidneyof the male Chamaeleo calyptratus (veiled chameleon). Int. J. Morphol., 39(4):1200-1211, 2021.

SUMMARY: This study aimed to describe the morphology, histology, and histochemistry of the kidneys and the sexual segment of the kidney (SSK) in Chamaeleo calyptratus (Yemen chameleons or veiled chameleons) collected during the active reproductive season. To achieve this objective, a total of 7 mature male Chamaeleo calyptratus were captured from their natural habitats from different areas in the Aseer region of Saudi Arabia and transferred to the reptilian laboratory where their kidneys were dissected out. Next, a morphological examination was conducted on the kidneys and the SSK was processed for light microscopic examinations with the primary focus placed on the morphology and histology of the SSK. The results of the study showed that Chamaeleo calyptratus possess two, reddish-brown, attenuated kidneys divided into lobes and lobules (lobulated). The histological study showed that the chameleons had no distinct limits between the cortex and medulla of the kidneys. In general, similar with other reptiles, this lizard demonstrated that the kidneys have few nephrons, do not show any nephron loop (loop of Henle), and display few glomeruli. The nephron is generally composed of standard components: renal corpuscle, glomerulus surrounded by a double-walled, the glomerular capsule (Bowman's capsule) and renal tubules (six renal tubular segments differentiated as the ciliated neck segment [between the glomerulus and the proximal segment], proximal segment, ciliated intermediate segment instead of nephron loop that connects proximal and distal, distal segment, terminal segment or sexual segment, and all segments emptying into the collecting ducts. The epithelial tissues lining the lumen of these segments vary from simple cuboidal cells to columnar and tall columnar cells in the SSK. Mature male Chamaeleo calyptratus possess hypertrophied parts of the distal renal segments, which are called the SSK. Histologically, the active SSK consists of simple tall columnar epithelial cells with rounded basal nuclei with clear centralized nucleoli and numerous apical coarse secretory granules which are released from the cells by an apocrine process. Histochemically, the secretory granules stain positively for proteins with mercuric bromophenol blue and react intensely to periodic acid-Schiff (PAS) for neutral carbohydrates. This is the first report about the histology of the SSK of the Chamaeleo calyptratus, and this study adds to the knowledge of the reproductive biology, biodiversity, and reproductive strategies of chameleons. Further studies are required to investigate the ultrastructure of the kidneys and SSK.

KEY WORDS: Veiled chameleon; Chamaeleo calyptratus; Reptiles; Squamata; Renal sexual segment; Histology.

\section{INTRODUCTION}

Reptiles compose a clade of the oldest fully terrestrial vertebrates on the planet. The reptilian family Chamaeleonidae is noted for morphological characteristics, such as a prehensile tail, independently rotating eyes, a ballistic tongue, and the ability to change colors. The chameleons are most noted for their adaptive skin, and a great body of research has been dedicated to their vision and integument (Laslie, 2018).
Chamaeleo calyptratus (veiled Yemen chameleons) can live in high, dry plateaus of mountainous regions, forests, and valleys of southern Saudi Arabia and Yemen. They are one of a few species of chameleons that can tolerate a wide range of temperatures from $23-35{ }^{\circ} \mathrm{C}$. Veiled chameleons are arboreal lizards that are highly independent and prefer to live high in trees. Males have a larger body (17-24 inches) and casque (head crest or helmet) when mature. The lifespan

\footnotetext{
${ }^{1}$ Department of Biology, College of Science, King Khalid University, Abha, Saudi Arabia.

${ }^{2}$ Department of Anatomy and Histology, Faculty of Medicine, Sana'a University, Sana'a, Republic of Yemen.
} 
of a veiled chameleon is usually eight years for males and five years for females (Lustig et al., 2013). Veiled chameleons reach sexual maturity at 4-5 months (Bartlett $\&$ Bartlett, 1995). Similar with mammals, males of the order Squamata of reptiles (lizards and snakes) have structures to the seminal vesicles called the sexual segment of the kidney (SSK) (Moura et al., 2014). Although the morphology and histology of Chamaeleon organs, such as the tongue, skin, and eyes, have been described by many investigators, few studies have focused on the kidneys, particularly the histochemistry and ultrastructure in this taxon. In recent years, the reptilian kidney has been increasingly studied due its fundamental role in understanding the phylogenic level of this group of vertebrates (Allam \& Abo-Eleneen, 2013).

The current taxonomy list of Chamaeleo calyptratus is the following: Kingdom Animalia - Animal; Subkingdom Bilateria; Infrakingdom Deuterostomia; Phylum Chordata - chordates; Subphylum Vertebrata - vertebrates; Infraphylum Gnathostomata; Superclass Tetrapoda; Class Reptilia - Reptiles; OrderSquamata - Lizards; Suborder Iguania - Iguanas; Family Chamaeleonid - Chameleons; Subfamily Chamaeleoninae; Genus Chamaeleo Chameleons; Species Chamaeleo calyptratus; Infraspecies Chamaeleo calyptratus calyptratus (Uetz \& Hosek, 2017).

Anatomically, the reptilian urinary tract includes paired kidneys, paired ureters, cloaca, and bladder. The kidneys of reptiles are located retroperitoneally in the caudal part of the abdominal cavity or in the pelvic cavity of lizards (Dantzler, 2005). They are generally small, attenuated, reddish-brown, and lobulated with a narrow posterior portion. Each kidney is encased in a thin capsule (Zwart, 1964; Jacobson, 2007; Khalef \& Ata, 2010). The kidneys of reptiles generally have structural and functional units called nephrons with structural modifications caused by the biological adaptation to different environments. Ureters are generally inserted into the cloaca and urates/urine are stored in a separate urinary bladder (Dantzler, 2005; Gibbons, 2007; Clayton, 2012). Previous studies indicated that reptile kidneys have some similarities and differences with mammalian kidneys. Anatomical similarities in the tubular system include the renal glomerular capsule (Bowman's capsule), proximal convoluted tubule, distal tubule, collecting duct, and ureter. The reptilian nephron is shorter than those in mammals and is divided into the following parts: renal corpuscle, neck segment (between the glomerulus and the proximal segment), proximal segment, intermediate segment, distal segment, terminal segment or sexual segment, and collecting duct, all of which are surrounded by delicate interstitial loose connective tissue and fibroblasts around the tubules and SSK. The neck segment is composed of cuboidal cells having cilia. The proximal tubule is lined by low columnar cells with well-developed microvillus called brush margin. The intermediate segment has an initial ciliated region lined by cuboidal cells that is followed by an area of mucus cells. The distal tubule is lined by cuboidal cells without brush margin, followed by a collecting duct which is lined by low columnar cells (Zwart, 1964; Jacobson; Dantzler, 2016). The reptilian nephron lacks the loop of the Henle and instead has a short intermediate segment. Reptiles have relatively few nephrons (from 3,000 to 30,000 in lizards), whereas each human kidney has one million nephrons (Zwart, 1964; Jacobson; Allam \& Abo-Eleneen). Snakes and lizards have many tubules and few glomeruli with 40-70 nm diameters (Mcnab, 2002). The renal corpuscles of lizards are composed of glomerulus (a tuft of three to four capillaries) and the glomerular capsule (Jin et al., 1995). The glomerular capsule consists of an outer parietal and inner visceral glomerular layer (Jacobson).

The reptilian SSK was first studied and described in 1866 by Gampert while studying the urinary system of Natrix natrix. Regaud \& Policard (1903) were the first researchers who suspected that this enlarged segment of the male kidneys of Squamata might have a reproductive function, so they named it the "sexual segment", as there seemed to be seasonal fluctuations in this portion of the organ that correlated with cyclical variations in hormonal status (Rheubert et al., 2011; Novelli et al., 2018). The number and density of sexual coarse secretory granules contained in the cytoplasm can vary significantly depending on seasonal fluctuations and species (Krohmer et al., 2004a).

Histologically, the SSK represents the hypertrophied part of the last distal tubules or secondary and tertiary collecting tubules of the kidneys that consist of simple tall columnar epithelial cells with rounded basal euchromatic nuclei with central nucleoli associated with mucous cells (Norris \& Lopez, 2011; Rheubert et al., 2014; Moura et al.). The SSK is an accessory sex organ found exclusively in male Squamates associated with each kidney that undergo seasonal changes according to testosterone cycles (androgen-dependent). The cycle of the SSK was classified into stages: (1) SSK not hypertrophied; (2) SSK hypertrophied with a few granules; (3) SSK cytoplasm full of secretory granules; (4) SSK secretory granules apically in the cytoplasm; and (5) maximum density of SSK secretory granules (Krohmer et al., 2004b).

Ultrastructurally, most studies regarding the ultrastructure of the active SSK concluded that the SSK consisted of tall columnar cells with centrally located nuclei and numerous apical electron dense secretory granules of various sizes within the apical cytoplasm (filling approximately $4 / 5$ of the total cell) which were released by an apocrine process (Rheubert et al., 2014). Studies on lizards 
and snakes to date have reported that the SSK is hypertrophied with high density with large secretory granules only during breeding season (during the months of March through August), and SSK atrophy occurs during the period of testicular quiescence when androgen levels decrease (Sever \& Hopkins, 2005; Al-Amri et al., 2013). During inactive months or quiescence, the SSK is nondistinguishable from the distal tubule or collecting ducts and the granules are distributed throughout the cytoplasm in small, condensed groups (Krohmer et al., 2004a). SSK hypertrophy is highly correlated with the level of testosterone during active mating season (March-August). Also, the SSK cells have Golgi complex, rough endoplasmic reticulum, abundant mitochondria, vesicles, mucoidal vacuoles, and thin intercellular canaliculi (Rheubert et al., 2011).

Histochemically, secretions of the SSK are rich in phospholipids which vary during different months of the year and contain acid phosphatase. The lipids of the SSK come from the kidney and liver for synthesis of lipid-rich secretions mixed with sperm and are released into the female genital tract during copulation (Prasad \& Reddy, 1972). Their granules stain positively for proteins with bromophenol blue and react with periodic acid-Schiff (PAS) for neutral carbohydrates (Sever \& Hopkins).

Physiologically, the function of the SSK is not clearly understood but the secretions of the sexual segment may help the sperm and is believed to provide seminal fluid that mixes with sperm. The SSK in male chameleons produces a secretion rich in proteins and lipids, which is used as a copulatory plug (O'Malley, 2005; Reavill \& Schmidt, 2010). In Squamates, the seminal fluid (complex of glycogen, mucopolysaccharides, mucoproteins, and lipids) secretes from the epididymis and the SSK utilizes the spermatozoa to nourish and activate the sperms in the female genital tract during copulation and is responsible for the production of pheromones. When the SSK becomes enlarged, it is vi-sible to the naked eye. The enlargement is caused by the whitish secretum accumulating as fine granules in the epithelial cells (Zwart, 2006). The SSK hypertrophied with maximum activity during the peak of the reproductive season, regressed with the lowest activity during the non-reproductive season during testicular quiescence and was stimulated to a secretory state by androgens (Prasad \& Reddy; Leonard \& CordobaAguilar, 2010; Moura et al.). Lizards, unlike snakes, demonstrate complete involution of the SSK (Krohmer et al., 2004b). The SSK is an important reproductive organ to be studied to enhance our comprehension of the reproductive biology of Squamates (Melo et al., 2019).

The most recent morphological and histological studies on the kidneys of Squamata have revealed the enlargement of the last portion of the nephron of males is called the SSK and it is usually not present in females or immature males (Regaud \& Policard; Sanyal \& Prasad, 1966; Gabri, 1983; Jacobson; Mendes et al., 2009; Rheubert et al., 2014; Novelli et al.). The present study aimed to investigate the histological and histochemical studies on the kidney and SSK in male Chamaeleo calyptratus.

\section{MATERIAL AND METHOD}

Chameleons. Seven, 1-year-old,175-190 g, adult, sexually mature, male, veiled chameleons (Chamaeleo calyptratus) were utilized in this study (Fig. 1). The animals were captured from Abha City, Aseer region, Saudi Arabia, between March and September 2019, when they were in the reproductive activity period. The captured animals were transported to the reptilian laboratory of the Biology Department, College of Science, King Khalid University, where all experimental procedures were performed. The animals were kept in

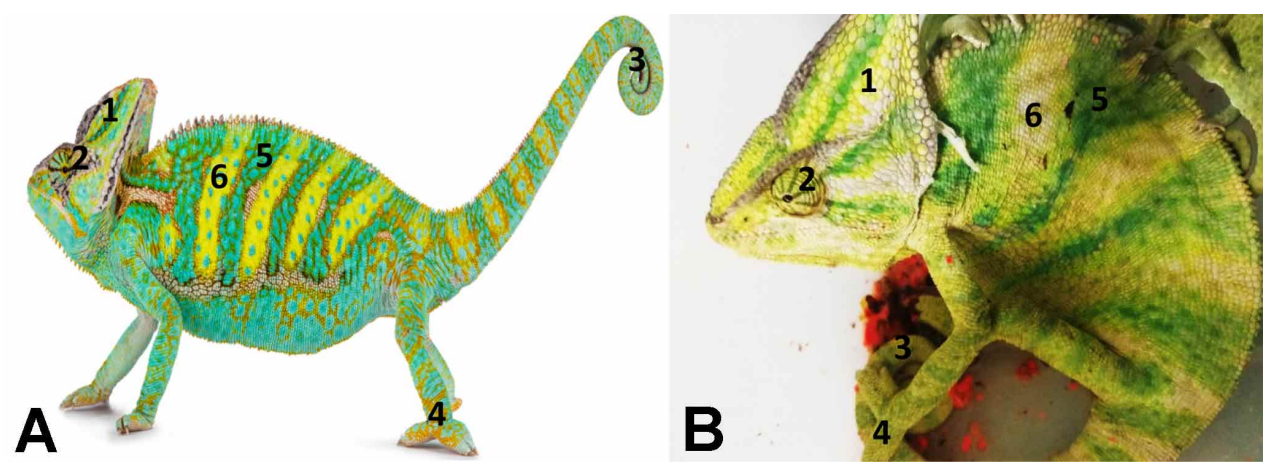

Fig. 1. External features of sexually mature male veiled chameleon (Chamaeleo calyptratus) that utilized in this study.(1): Helmet -like casque on head, (2):Black eye with small yellow eye ring, (3): Long prehensile tail, (4): 5-toed claw-like feet, (5): Brown, tan, turquoise, green and white scaly skin that change the color with change the temperature, (6): Cream patches with turquoise spots.A: Veiled chameleon (Chamaeleo calyptratus) (Pfeifer, 2019; Khan et al., 2019), B: our caught chameleon. 
ambient temperatures $\left(23 \pm 1.5^{\circ} \mathrm{C}\right)$ with natural photoperiods (i.e., 12 hours of a light-dark cycle). After being captured and transported to the laboratory, the individuals were anesthetized with ether and submitted to morphological studies. All animals were euthanized in accordance with the standards set forth in the guidelines for the care and use of experimental animals by Research Ethics Committee King Khalid University (ECM\#2021-5507).

Histological and histochemical studies. For the histological studies, the animals were opened through a medium incision from the cloaca as far as the anterior limbs, exposing the reproductive organs for macroscopic analyses by removing the rib cage and coelomic wall on one side, thus exposing all the visceral organs (Fig. 2) according to Jacobson and Martinson (2013). Fresh portions of the kidneys (5 $\mathrm{mm}$ in size) from each chameleon were cut rapidly and fixed in neutral buffered formalin (10\%) for 48 hours. The fixed specimens of the kidney were processed for paraffin techniques according to the method described by Al-Doaiss (2020), dehydrated with grades of ethanol (70, 80, 90, 95 and $100 \%$ ), cleared in 2 changes of xylene and impregnated with 2 changes of molten paraffin wax, using an automatic tissue processor (Sakura, Japan). The specimens were embedded and blocked out using an embedding station (Sakura, Japan) and a series of section thicknesses $(4-5 \mu \mathrm{m})$ were cut using a microtome (ModelRM2245, Leica, Germany). The renal sections were stained with the following stains: hematoxylin-eosin (H\&E) for general histology, periodic acid-Schiff (PAS) for neutral carbohydrates, Alcian blue (AB) at $\mathrm{pH} 2.5$ to demonstrate neutral mucopolysaccharides, mercuric bromophenol blue (MBPB) for detection proteins, and Masson trichrome for collagen fibers, staining done by using an auto stainer machine (Model 5020, Leica, Germany). All stained sections were examined and photographed by using an optical microscope (Olympus Microscope BX53 with Digital Camera, Japan). Staining procedures followed the techniques of Suvarna et al. (2019).

\section{RESULTS}

Morphology of the kidney and SSK. At the gross anatomy level, the kidneys of male Chamaeleo calyptratus are reddish-brown, paired, symmetrical, elongated, and slightly lobulated compact organs located in the mid-caudal, dorsal coelom, lateral to the lumbar spine above the testes. The kidneys typically lie within the pelvic canal of most lizards, particularly chameleons (Figs. 3A,B). Like other reptilian kidneys, mature male Chamaeleo calyptratus kidneys are made up of many tiny renal lobules combined into lobes. The kidneys are composed of functional units, called nephrons. The nephrons of kidneys consist of renal corpuscle, proximal, intermediate, and distal segments which drain into a collecting duct system. Collecting ducts from each lobule empty into a separate branch of the ureter. Many reptiles live in dry environments and can convert waste nitrogen compounds into quite insoluble uric acid secreted by the tubules into the cloaca as white paste. Thus, reptile glomeruli are quite small, and some reptiles have no renal glomeruli at all. Nephrons filter initial urine from the blood, reabsorb water and nutrients, and secrete wastes, producing the final urine, which is expelled. Sexually mature male Chamaeleo calyptratus possess hypertrophied parts of the distal renal tubules, called SSK, before entering the collecting ducts. The sexual segment in mating season is highly hypertrophied and actively secretory more than during other seasons. This sexual segment can enlarge and swell during heightened reproductive activity (Fig. 4).

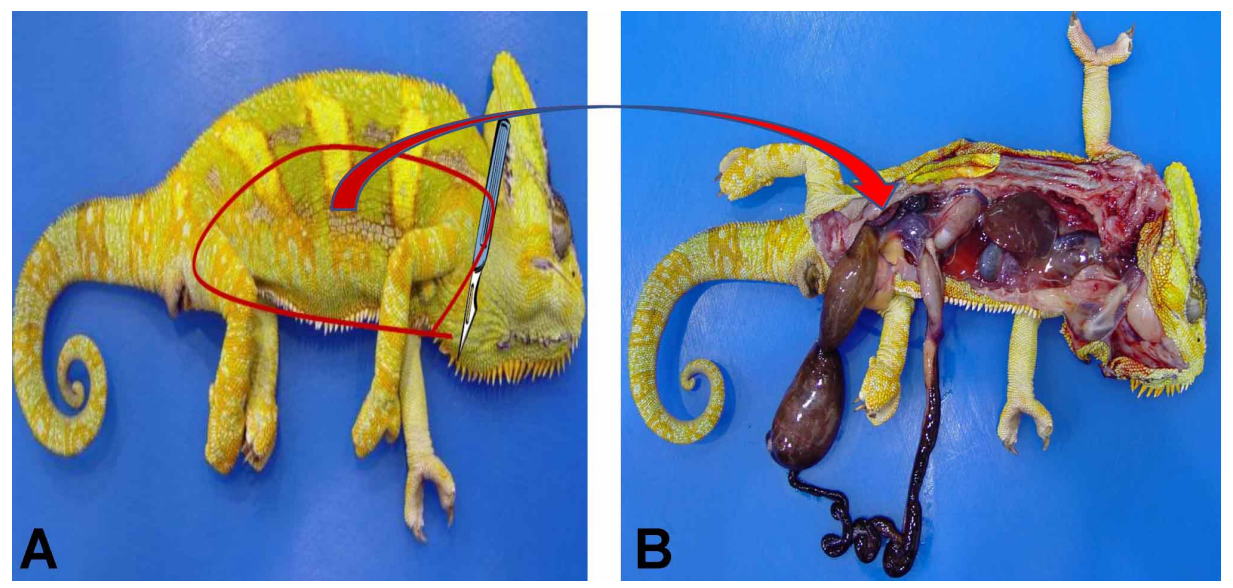

Fig. 2. Photomicrograph showing the dissecting mode adapted from Jacobson (2007) and Martinson (2013): The animal was opened through medium incision from the cloaca as far as anterior limbs, exposing the reproductive organs to macroscopic analyses by removing the rib cage and coelomic wall on one side, thus exposing all of the visceral organs. 

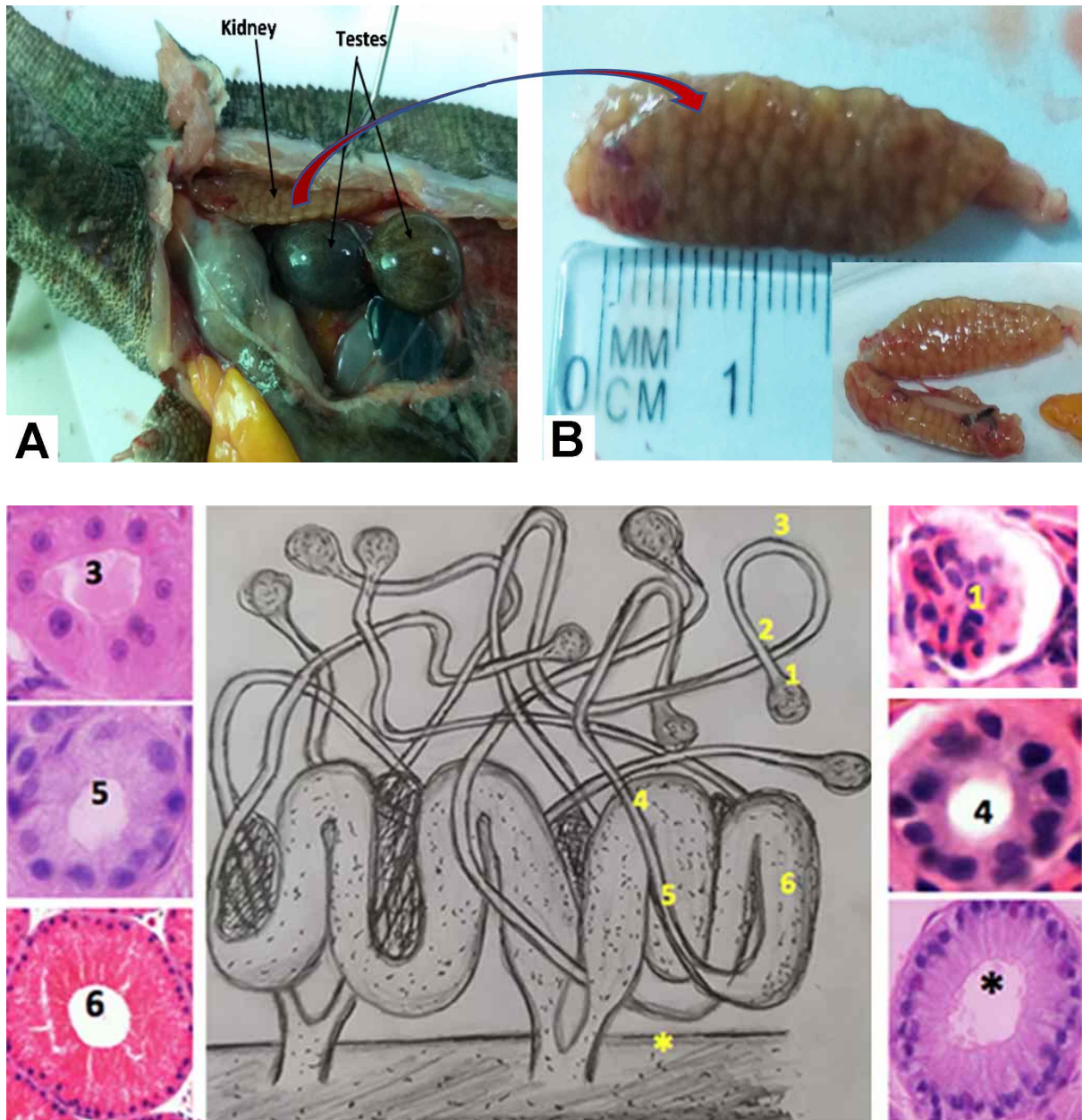

Fig 3. A. Photomicrograph showing paired kidneys and paired testes within coelomic cavity (viscera) of veiled chameleon; both kidneys are pale to brownishredelongated organs and contain lobules. The fat pads are yellow and have been reflected from the coelom (*). B. Photomicrograph of kidney of male Chameleon (Chamaeleo calyptratus) showing brownish-red elongated lobulated kidneys.

Fig. 4. Overview of schematic drawing of the nephron in male of the Squamata (snakes, and lizards «chameleons»), as observed during reproductively active period detailing the histology of each region. The nephron consists of:(1): Glomerulus,(2): neck segment, (3): Proximal segment, (4): intermediate segment "a short transitional portion between proximal"(5): distal segment, sexual segment "dilated distal part" and collecting duct(*). H \& E. $\times$ 400. Adapted from Sever et al., 2002.
Histological and histochemical studies of the kidney and SSK. Light microscopy of the sexually mature males showed the structure of the kidneys and the renal sexual segment with some histological characteristics. These sexual segments were localized in clusters and dis-tributed as wedge-shaped throughout the kidneys between the renal tubules (Fig. 5A). The light microscopy analysis revealed that the renal parenchyma of male Chamaeleo calyptratus consists of the cortex and medulla but with no separation between them. Chamaeleo calyptratus kidneys consist of well-defined nephron components (renal corpuscles, proximal, intermediate, distal segments, and collecting duct). The renal corpuscles consist of a tuft of blood capillaries known as a glomerulus, surrounded by squamous visceral and parietal epithelium forming the glomerular capsule associated with renal space between them, with a visceral layer in direct contact with the capillaries of the glomerulus. The proximal tubule was lined by simple cuboidal to low columnar epithelium with acidophilic cells that were stained more intensely at brush margin (microvilli) at the apices of the cells with basal rounded nuclei. The intermediate segment was lined by a simple cuboidal epithelium with cilia and the nuclei were in a basal position. The distal tubule was lined by simple cuboidal to low columnar epithelial poorly acidophilic and smaller diameter with basal nuclei. The distal tubule enlarged dramatically as it transitioned into the SSK and the SSK had the largest diameter in the renal tubule with tall columnar epithelial. The collecting ducts were lined with low columnar epithelia (Figs. 5B,C). The SSK was distributed between renal tubules and lined by simple tall columnar glandular epithelial cells rest on clear basement membrane (basal lamina) with basally positioned nuclei and clear intracanaliculi between the cells (Figs. 5D and 6A-D). The cytoplasm of SSK cells, containing mature secretory eosinophilic granules, stain intensely with H\&E stain. Intensely stained granules extend from the nuclei apically to the lumen. The number and density of these granules in the cytoplasm vary according to the hormonal status of the species and from one individual to another. The nuclei of SSK cells are rounded basal located with clear centrally located nucleoli and central translucent colloidal material collected in the lumen of tubules (Figs. 7A-C). Regarding 

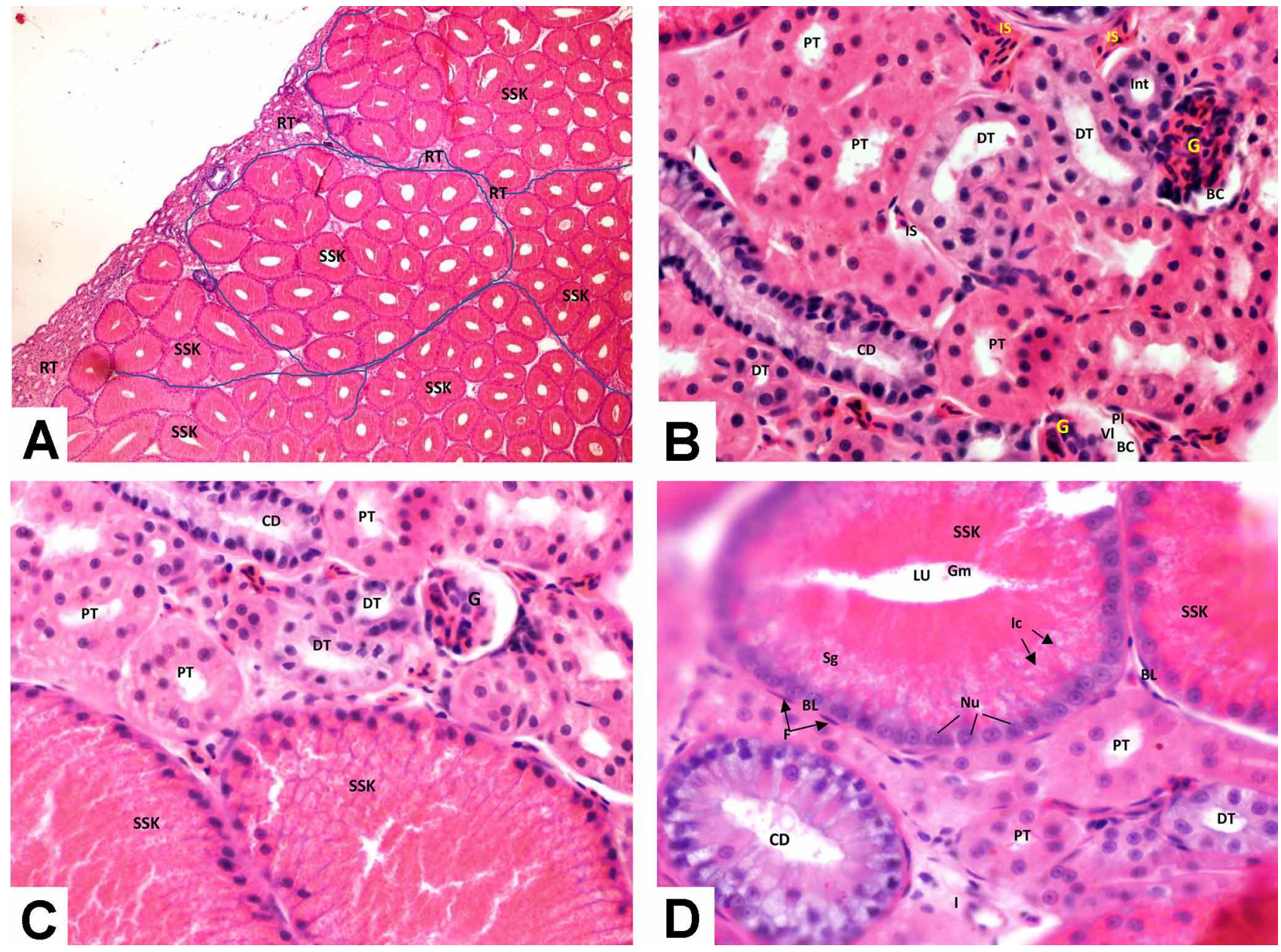

Fig. 5. A. Photomicrograph of the kidney of male Chamaeleo calyptratus showing representative density of sexual segments of kidney during breeding season. The sexual segments are hypertrophied and localized in clusters, dis-tributed as wedge-shaped throughout the kidney between the renal tubules (RT). H \& E. $\times 400$. B. Photomicrograph of the kidney of a male Chamaeleo calyptratus showing cross section within parenchyma of the kidney with the sexual segments (SS). Two renal corpuscles are seen, each one consists of tuft of blood capillaries known as a Glomerulus (G) surrounded by the visceral (Vl) and parietal layer (Pl) of glomerular capsule (BC). Proximal tubules (PT) have large diameters lined by simple cuboidal epithelial cells with brush margin that lines the apices of the epithelial cells and an eosinophilic cytoplasm. Distal tubules (DT) have small diameters lined by simple cuboidal epithelial cells with a basophilic cytoplasm. Intermediate tubules (Int) have small diameters lined by simple cuboidal epithelial cells with a basophilic cytoplasm. Collecting duct (CD) lined by simple columnar epithelium, Blood vessels in the interstitium (IS). H \& E. $\times 400$. C. Photomicrograph of kidney of male veiled chameleon (Chamaeleo calyptratus) showing the nephron of the kidney that composed of: glomerulus (G), proximal tubules (PCT), Distal tubules (DT), Collecting duct (CD), the SSK is completely occluded by large, deeply red-staining granules seen in the cytoplasm of sexual segment (SSK). H \& E. $\times 400$. D. Photomicrograph of the kidney of male Chamaeleo calyptratus showing cross section within the sexual segments and proximal (PT) and distal (DT) renal tubules; basal lamina (BL) with fibroblasts (F); granular material $(\mathrm{Gm})$; intercellular canaliculus $(\mathrm{Ic})$; lumen $(\mathrm{Lu})$; nucleus $(\mathrm{Nu})$; secretory granules $(\mathrm{Sg})$ contain numerous small red protein

the carbohydrate histochemistry, the secretory granules of the SSK stained intensely and reacted positively with magenta color, the basement membranes renal tubules and microvilli of proximal tubules also positively stained with PAS for neutral carbohydrates (Figs. 8A,B). The epithelial cells of the rental tubules and the SSK stained intensely with mercuric bromophenol blue technique $(\mathrm{MBPB}+)$ for proteins (Fig. 9A); darkly stained blue secretory granules fill the apices of all the epithelial cells of the SSK (Figs. 9B,C). The secretory granules product most likely contained a glycoprotein or mucoprotein. The glomerulus, epithelium of renal tubules and the cytoplasmic granules of the SSK were stained very weak positively or did not react with $A B$ at pH 2.5 (Fig. 10A). Cytoplasmic secretory granules of sexual segments stained red and the basement membrane stained blue with Mallory trichrome stain (Fig. 10B). 

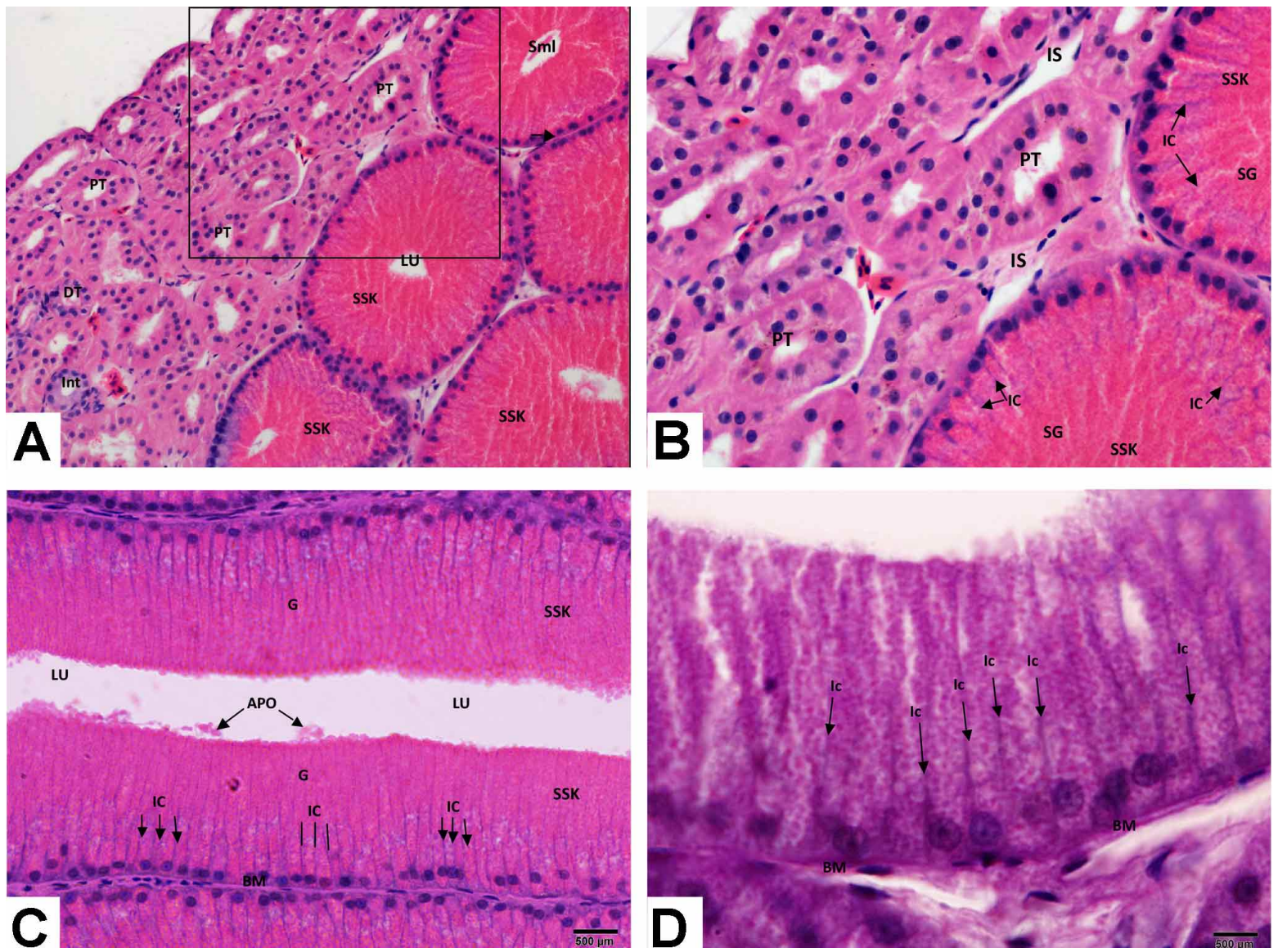

Fig. 6. A. Cross section stained with H \& E through the kidneys of male Chamaeleo calyptratus. Areas in the sexual segments (SSK) with mature secretory granules, proximal tubule (PT); distal tubules (DT); Intermediate tubules (Int); lumen (Lu); secretory material in the lumen $(\mathrm{Sml})$; sexual segment $(\mathrm{SS})$. H \& E. $\times 200$. part inside the square magnified in the next Figure. H \& E. $\times 200$. B. Enlarged view of selected area of kidney of a male Chamaeleo calyptratus exhibited cross sections within the proximal tubules (PT), interstitial connective tissue (IS), two sexual segments (SSK) filled with coarse red-staining granules in the apical portion of the cytoplasm (SG), intracanalicular intercellular canaliculi (Ic) also are seen. H \& E. $\times 400$. . C. Photomicrograph of longitudinal section in the sexual segments of the kidney (SSK) of male Chamaeleo calyptratus. The SSK lined by tall columnar epithelial cells rest on visible basement membrane (BM), apocrine secretin (APO) in the lumen (LU), lamina propria connective tissue (LP) contains fibroblast (F), intercellular canaliculi (IC). H \& E. × 400. D. Oil immersion Photomicrograph of the sexual segment of the kidney (SSK) of male Chamaeleo calyptratus with clear intercellular canaliculi (IC) between tall columnar epithelial cells and visible basement membrane (BM). PAS stain. $\times 1000$.

\section{DISCUSSION}

The aim of the present study was to determine the histology and histochemistry of the renal SSK of male Chamaeleo calyptratus during breeding season using light microscopy. Classic special histologic techniques were used. The kidney has become the subject of intensive investigations by both histologists and physiologists (Anderson, 1960).

Anatomically, the kidneys of reptiles are located in the caudal part of the abdominal cavity or retroperitoneally in the pelvic cavity of lizards. Kidneys are attenuated, reddish-brown, and divided into lobes and lobules (Zwart, 1964). Microscopically, the reptilian kidney consists of nephrons, with glomeruli and renal tubules that compare to mammals, amphibia, and birds, but also with renal tubules that are short in comparison to those of mammals. A thin layer of interstitial connective tissue separates the reptilian nephrons and divides the parenchyma of the kidneys into lobes and lobules (Zwart, 1964).

The results of this study demonstrated that the kidneys 

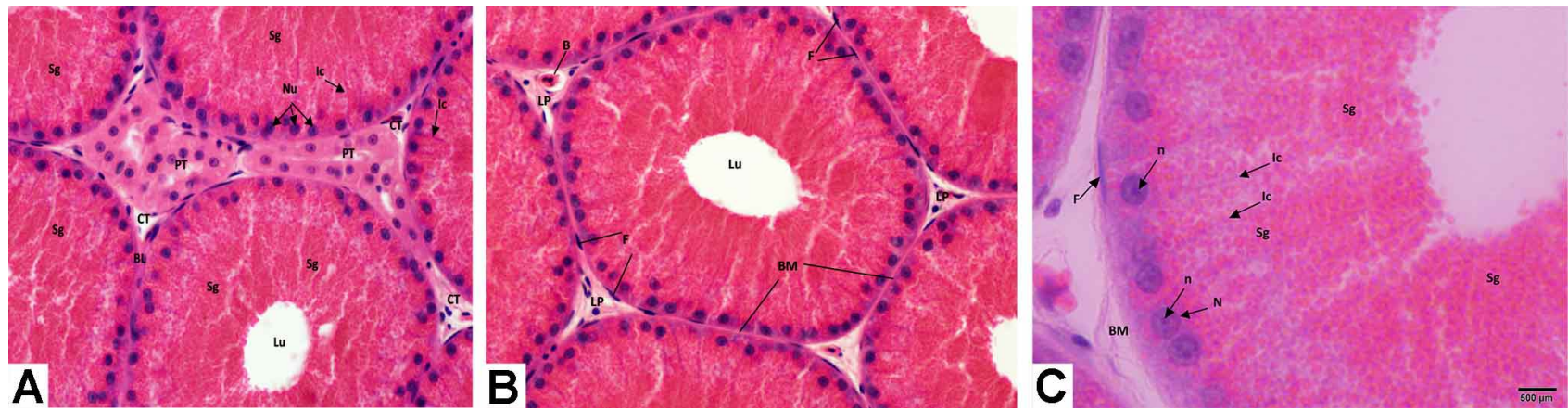

Fig. 7. A. Photomicrograph of the cross section within the sexual segments of the kidney of male Chamaeleo calyptratus showing rounded tubules with basal lamina (Bl) separates high columnar epithelial cells from the surrounding connective tissue (CT); mass of eosinophilic cytoplasmic coarse secretory granules ( $\mathrm{Sg}$ ) (contain numerous small red protein droplets) scattered throughout the cytoplasm; lumen $(\mathrm{Lu})$; basally situated rounded nuclei $(\mathrm{Nu})$; Proximal tubules $(\mathrm{PT})$ are situated between the sexual segments. H \& E. $\times 400$. B Photomicrograph of cross section in the sexual segments of the kidney of male Chamaeleo calyptratus showing pentagonal or rounded sexual segments of the kidney with wide lumen (Lu), lamina propria connective tissue (LP) contains fibroblast (F) and holds blood capillary (B), sexual segments lined by tall columnar epithelial cells rest on visible basement membrane $(\mathrm{BM})$. H \& E. $\times 400$. C. Oil immersion Photomicrograph of the cross section within the sexual segment of the kidney of male Chamaeleo calyptratus showing high columnar epithelial cells with basally rounded nuclei $(\mathrm{N})$ with clear nucleoli (n); mass of eosinophilic cytoplasmic coarse secretory granules $(\mathrm{Sg})$ (contain numerous small red protein droplets) scattered throughout the cytoplasm; basal lamina (B1) with fibroblast (F). intercellular canaliculi (IC). H \& E. × 1000 .
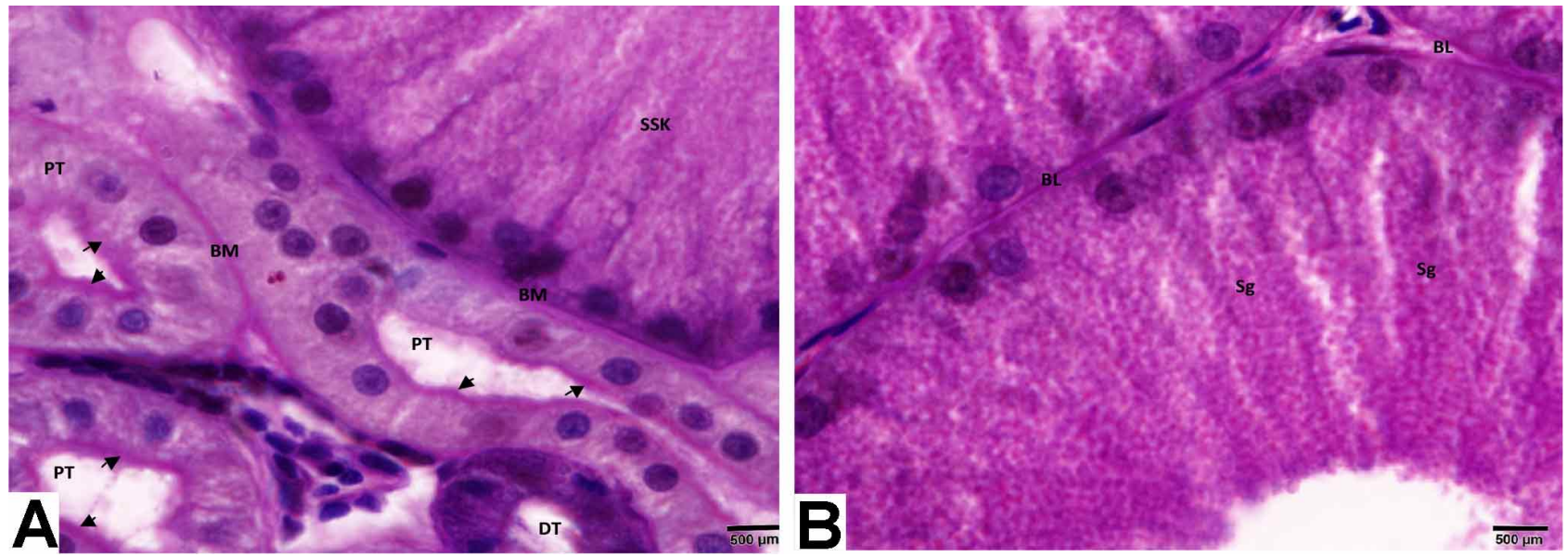

Fig. 8. A. Oil immersion Photomicrograph of the kidney of a male Chamaeleo calyptratus showing cross section within the proximal tubules (PT), distal tubule (DT) and sexual segments of the kidney (SSK) with positively-staining cytoplasmic secretory granules with magenta colour. The basement membranes (BM) and microvilli (arrows) also positively-staining with periodic acid and Schiff's (PAS+) for neutral carbohydrates. $\times 1000$. PAS stain. B. Oil immersion Photomicrograph of the kidney of a male Chamaeleo calyptratus showing cross section within the sexual segments with magenta color positively staining cytoplasmic secretory granules ( $\mathrm{Sg}$ ). The basal lamina (BL) also positively-staining with periodic acid and Schiff's (PAS+) for neutral carbohydrates. $\times 1000$. PAS stain.

of male Chamaeleo calyptratus are composed of renal parenchyma with the cortex and medulla merged. The renal parenchyma is composed of structural and functional units called nephrons. The nephrons of male Chamaeleo calyptratus are composed of six distinct renal segments: A renal Malpighian corpuscle glomerulus, a neck segment, a proximal convoluted tubule, an intermediate tubule, a distal convoluted tubule, and sexual segment/collecting duct. The reptilian renal corpuscle is the first part of each nephron, the renal corpuscle is composed of a glomerulus enclosed by the glomerular capsule that is composed of simple squamous epithelial parietal and visceral layers comparable to other vertebrates. The neck segment connects the glomerulus to the proximal tubule. The intermediate segment connects the proximal to the distal tubule and is lined by simple cuboidal epithelial ciliated cells. The intermediate segment gradually merges into the distal tubule. The morphology and histology of the intermediate segment of male Chamaeleo calyptratus 

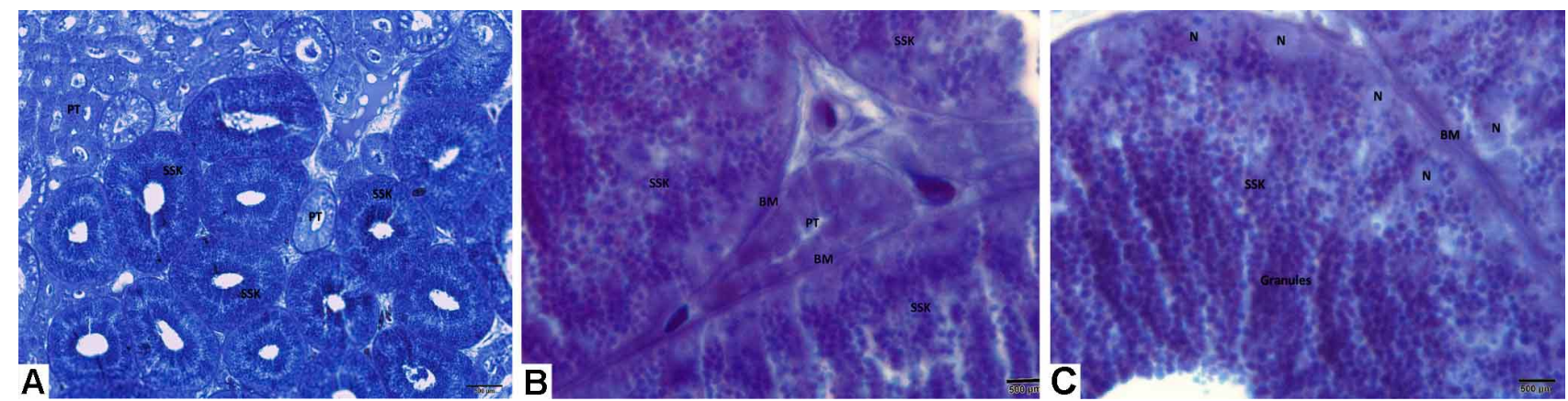

Fig. 9. A. Photomicrograph of the kidney of a male Chamaeleo calyptratus showing cross section within renal tubules and sexual segments. Epithelial cells of tubules and sexual segments react positively with mercuric bromophenol blue (MBPB+) is specific for identifying protein.PT (proximal tubule), SSK (sexual segments of kidney). $\times 400$.B. Photomicrograph of the kidney of a male Chamaeleo calyptratus showing cross section within renal tubules and the epithelial cells of three sexual segments. Epithelial cells of tubules and the cytoplasmic secretory granules of sexual segments react positively with mercuric bromophenol blue (MBPB+) is specific for identifying protein.PT (proximal tubule), SSK (sexual segments of kidney), BM (basement membrane). $\times 1000$. C. Photomicrograph of the kidney of a male Chamaeleo calyptratus showing cross section within the sexual segment. Dark blue secretory granules fill the apices of all of the epithelial cells in SSK. SSK (sexual segments of kidney), BM (basement membrane), N (nucleus). Mercuric bromophenol blue $(\mathrm{MBPB}+) \times 1000$.
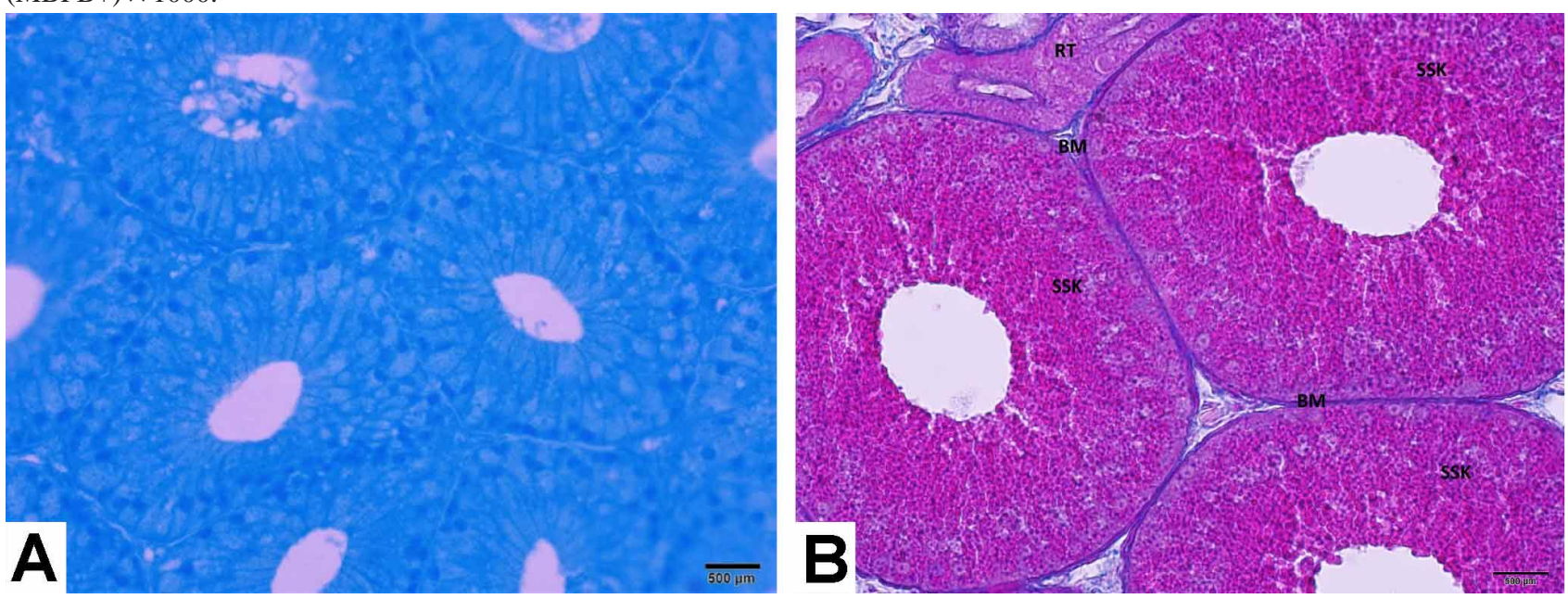

Fig. 10. A. Photomicrograph of the kidney of a male Chamaeleo calyptratus showing cross section within the sexual segments. The cytoplasmic secretory granules react very weakly with Alcian blue $(\mathrm{AB})$ at $\mathrm{pH}$ 2.5. Alcian blue is generally considered specific for identifying acid mucosubstances whereas alcianophilia at pH 2.5. SSK (sexual segments of kidney), Lu (lumen). $\times 400$. B. Photomicrograph of the kidney of a male Chamaeleo calyptratus showing cross section within renal tubules (RT) and sexual segments with red color cytoplasmic secretory granules $(\mathrm{Sg})$. The basement membrane $(\mathrm{BM})$ positively-staining (blue) with Mallory trichrome stain. $\times 400$.

is similar with the thick ascending part of the nephron loop (loop of Henle) in mammals. In male snakes and lizards, the terminal distal tubule becomes hypertrophied to form the sexual segment at the peak of sexual activity. The SSK is lined by tall columnar cells that reach a height two to four times higher than that during non-sexual activity. They are filled with large secretory granules which are extruded into the lumen. The abundance and density of the sexual granules change according to seasonal fluctuations. During sexual breeding season, the SSK is characterized by maximum hypertrophy and the cells are completely occupied by coarse darkly stained granules, but during sexual quiescence the granules are distributed throughout the cytoplasm in small aggregations. The nephron of the female is similar that of the male but lacks the sexual segment of the kidney (Zwart, 1964). All these features of kidney histoarchitecture examined in the male Chamaeleo calyptratus were similar with those of other reptilians, such as Notomabuya frenata and Aspronema dorsivittatum (Squamata) (Novelli et al.) and Urommastyx microlopis (Krohmer et al., 2004a,b; Khalef \& Ata).

The hypertrophied nephron region of reptilian kidneys is called the renal sexual segment and is found only in male Squamates (reptiles and snakes). It was described for the first time by Gampert (1866) (Reguad \&Policard, 
1903). The histology of the SSK of reptiles was described initially by Fox (1977) as a simple columnar epithelial cell with rounded basally located nuclei. Previous studies on Squamates showed some variation in the SSK location. The SSK of snakes is located as part of the terminal segment before entering the collecting duct. The SSK of lizards is located at the distal tubule, involved as a small part of the collecting ducts or part of the ureter (Rheubert et al., 2014).

In this study, simple tall columnar epithelial cells of the SSK were observed, with rounded nuclei in the basal portion and coarse secretory granules scattered throughout the cytoplasm extended from the medial to the apical portion of SSK cells. These histological features of the SSK have been observed in several species of Squamata, such as Teretrurus sanguineus, Rena dulcis, Hydrophis ornatus, Hydrophis platurus, Ephalophis greyae, Aipysurus eydouxii, Naja samarensis,Micrurus tener (Sever et al., 2012), Scincella lateralis (Sever \& Hopkins), Hemidactylus turcicus (Rheubert et al., 2011), and Tropidurus torquatus (Mendes et al.).

Various articles have described the histology of the kidneys and SSK of reptiles, such as the species Mabuya brachypoda (Taylor, 1956; Hernandez-Franyutti et al., 2005) and Sceloporus grammicus.

The current study observed that the SSK of the male Chamaeleo calyptratus possessed coarse cytoplasmic secretory granules stain positively for carbohydrates (PAS) and proteins (mercuric bromophenol blue), but the AB reaction was weak, which indicated that the SSK were contained glycogen, proteins, neutral and mucosubstances. The carbohydrate content of the kidneys of male Chamaeleo calyptratus plays a role in the renal physiology of mammals and reptiles in nitrogenous waste excretion (Schimming \& Vicentini, 2000), these results are parallel with Sever \& Hopkins. Other studies found the secretory granules to always be rich in protein, but the PAS reaction was quite variable (Rheubert et al., 2014). Histochemical findings of the present study agree with previous studies that the secretory granules of the SSK of the small lizard, Eurolophosaurus nanuzae, reacted positively and consistently during the active reproductive season to the PAS method, Bromophenol blue, and Sudan black. A positive AB reaction was weak (Melo et al.). The chemical contents of the SSK varied throughout the reproductive cycle of adult male Chamaeleo calyptratus. During the reproductive season, the content of acid mucopolysaccharides, neutral mucopolysaccharides, proteins, and lipids were present in the SSK and RSS activity varied seasonally. These changes in the chemical composition of the SSK could be related to changes in the functionality of the SSK throughout the year (Melo et al.).

\section{CONCLUSION}

The present study concluded that the Chamaeleo calyptratus possesses two, reddish-brown, attenuated kidneys divided into lobes and lobules. Histologically, the chameleon has no distinct limits between the cortex and medulla of kidneys. The kidneys have few nephrons composed of the standard renal components. Mature male Chamaeleo calyptratus possess hypertrophied parts of the distal renal sexual segment lined by simple tall columnar epithelial cells with rounded basal nuclei and numerous apical secretory granules. The secretory granules stain positively with mercuric bromophenol blue for proteins and react intensely with PAS for neutral carbohydrates. This species is an excellent model for histological studies of this class. Additional histochemical and ultrastructural investigations are needed on the kidneys and sexual segment of Chamaeleo calyptratus to further understand this animal.

\section{ACKNOWLEDGMENTS}

The author extends appreciation to the Deanship of Scientific Research at King Khalid University, Abha, KSA for funding this work through the General Research Project under grant number (G.R.P./55/42).

AL-SHEHRI, M. A. \& AL-DOAISS, A. A. Estudio morfológico, histológico e histoquímico del segmento sexual del riñón del macho Chamaeleo calyptratus (camaleón velado). Int. J. Morphol., 39(4):1200-1211, 2021.

RESUMEN: Este estudio tuvo como objetivo describir la morfología, histología e histoquímica de los riñones y el segmento sexual en el riñón (SSK) del Chamaeleo calyptratus (camaleones de Yemen o camaleones con velo) recolectados durante la temporada reproductiva. Un total de 7 machos maduros de Chamaeleo calyptratus fueron capturados en su hábitat natural de diferentes áreas en la región de Aseer de Arabia Saudita y transferidos al laboratorio de reptiles donde fueron disecados los riñones. Posteriormente, se llevó a cabo un examen morfológico de los riñones y se procesó la SSK para exámenes con microscopio óptico con el enfoque principal puesto en la morfología y la histología. Los resultados del estudio mostraron que Chamaeleo calyptratus posee dos riñones atenuados de color marrón rojizo divididos en lóbulos (lobulados). En el estudio histológico se observó que los riñones de los camaleones no tenían límites definidos entre la corteza y la médula. En general, y similar a otros reptiles, este lagarto demostró que los riñones tienen pocas nefronas, no muestran ningún asa de Henle y presentan pocos glomérulos. La nefrona está compuesta por componentes estándar: corpúsculo renal (glomérulo rodeado por una pared de 
doble pared). Cápsula de Bowman y túbulos renales (seis segmentos tubulares renales diferenciados como el segmento del cuello ciliado [entre el glomérulo y el segmento proximal], segmento proximal, segmento intermedio ciliado en lugar del asa de Henle que conecta proximal y distal, segmento distal, segmento terminal o segmento sexual y todos los segmentos que desembocan en los conductos colectores Los tejidos epiteliales que recubren la luz de estos segmentos varían desde células cuboidales simples hasta células columnares y columnares altas en la SSK. Los machos maduros de Chamaeleo calyptratus poseen partes hipertrofiadas de los segmentos renales distales, denominados SSK. Histológicamente, la SSK activa consiste en células epiteliales cilíndricas altas simples con núcleos basales redondeados, nucléolos centralizados claros y gránulos secretores gruesos apicales que se liberan de las células por un proceso apocrino. Histoquímicamente, los gránulos secretores se tiñen positivamente para las proteínas con azul de bromofenol mercúrico y reaccionan intensamente al ácido periódico-Schiff (PAS) para obtener carbohidratos neutros. Este es el primer informe sobre la histología de la SSK de Chamaeleo calyptratus, y se suma al conocimiento de la biología reproductiva, la biodiversidad y las estrategias reproductivas de los camaleones. Se requieren más estudios para investigar la ultraestructura de los riñones y la SSK.

PALABRAS CLAVE: Camaleón velado; Chamaeleo calyptratus; Reptiles, Squamata; Segmento sexual renal; Histología.

\section{REFERENCES}

Al-Amri, I. A.; Mahmoud, I. Y.; Waring, C. P.; Alkindi, A. Y.; Khan, T.; Bakheit, C. \& Al-Mawali, K. M. The reproductive cycle of the male house gecko, Hemidactylus flaviviridis, in relation to plasma steroid concentrations, progesterone receptors, and steroidogenic ultrastructural features, in Oman. Gen. Comp. Endocrinol., 187:23-31, 2013.

Al-Doaiss, A. A. Hepatotoxicity-Induced by the therapeutic dose of acetaminophen and the ameliorative effect of oral co-administration of selenium/Tribulus terrestris extract in rats. Int. J. Morphol., 38(5):144454, 2020.

Allam, A. \& Abo-Eleneen, R. Comparative histological, histochemical and ultrastructural studies of the nephron of selected snakes from the Egyptian area. Biologia, 68(3):546-58, 2013.

Anderson, E. The ultramicroscopic structure of a reptilian kidney. $J$. Morphol., 106:205-41, 1960.

Bartlett, R. \& Bartlett, P. Chameleons. New York, Barron's Educational Series Inc., 1995.

Clayton, L. A. Reptile Renal Disease Overview and Case Workups. In: NAVC Conference 2012 Small Animal. Gainesville : North American Veterinary Conference, 2012.

Dantzler, W. H. Challenges and intriguing problems in comparative renal physiology. J. Exp. Biol., 208(Pt. 4):587-94, 2005.

Dantzler, W. H. Comparative Physiology of the Vertebrate Kidney. 2nd ed. Amsterdam, Springer, 2016.

Gabri, M. S. Seasonal changes in the ultrastructure of the kidney collecting tubule in the lizard Podarcis (= Lacerta) taurica. J. Morphol., 175(2):143-51, 1983.

Gibbons, P. M. Reptile and Amphibian Urinary Tract Medicine: Diagnosis and Therapy. Mount Juliet, Proceedings Association of Reptilian and Amphibian Veterinarians, Center, 2007.
Jacobson, E. R. Infectious Diseases and Pathology of Reptiles. Color Atlas and Text. Boca Raton, CRC/Taylor \& Francis, 2007.

Jin, S. M.; Rodrigues, A. M. \& de Souza, A. C. Histology and histochemistry of the kidney and ureters of the Caiman crocodilus yacare (Daudin, 1802)--Crocodilia Reptilia). Rev. Bras. Biol., 55(1):97-103, 1995.

Khalef, N. \& Ata, T. Histological Study of Lizard Kidney (Urommastyx microlopis). Diyala Agric. Sci. J., 2(2):1-8, 2010.

Khan, O.; Sims, W. \& Swinford, A. Isolation of Nannizziopsis sp. from skin lesions of a veiled chameleon (Chamaeleo calyptratus). Texas A\&M Veterinary Medical Diagnostic Laboratory, 2019. Available from: https://tvmdl.tamu.edu/2019/01/15/isolation-of-nannizziopsissp-from-skin-lesions-of-a-veiled-chameleon-chamaeleo-calyptratus/

Krohmer, R. W. Variation in seasonal ultrastructure of sexual granules in the renal sexual segment of the Northern Water Snake, Nerodia sipedon sipedon. J. Morphol., 261(1):70-80, 2004a.

Krohmer, R. W.; Martinez, D. \& Mason, R. T. Development of the renal sexual segment in immature snakes: effect of sex steroid hormones. Comp. Biochem. Physiol. A Mol. Integr. Physiol., 139(1):55-64, 2004b.

Laslie, K. C. Investigations of Biotremors in the Veiled Chameleon (Chamaeleo calyptratus). Master of Science Thesis. Masters Theses \& Specialist Projects. Paper 3067, 2018. Available from: https:// digitalcommons.wku.edu/theses/3067

Leonard, J. \& Cordoba-Aguilar, A. The Evolution of Primary Sexual Characters in Animals. Oxford, Oxford University Press, 2010.

Lustig, A.; Ketter-Katz, H. \& Katzir, G. Relating lateralization of eye use to body motion in the avoidance behavior of the chameleon (Chamaeleo chameleon). PLoS One, 8(8):e70761, 2013

Martinson, S. Necropsy Techniques and Common Diseases. In: Diagnostic Services, Atlantic Veterinary College, 2013. Available from: http:// people.upei.ca/smartinson/Reptile_pathology__necropsy_techniques.pdf

Melo, G. C.; Nascimento, L. B. \& Galdino, C. A. B. Lizard reproductive biology beyond the gonads: An investigation of sperm storage structures and renal sexual segments, Zoology, 135:125690, 2019.

Mendes, R. M. M.; Pinheiro, N. L.; Nascimento, A. A.; Santos, C. N.; Ribeiro, T. P.; Santos, M. A. \& Sales, A. Histologia Comparada de Testículo e do Segmento Sexual do rim de Lagarto Tropical Tropidurus torquatus adultos e imaturos. Rev. Univ. Rural Ser. Cienc. Vida, 29:1520, 2009.

Moura, C. S.; Silva, C. C.; Silva, S. V.; Cordeiro, E.; Silva, B.; Bezerra, R. S. \& Guerr, M. M. P. Activity of crude extract of the sexual renal segment from Crotalus durissus on spermatic kinematics of thawed dog semen. BMC Proc., 8(Suppl. 4):P150, 2014.

Norris, D. O. \& Lopez,? K. H. Hormones and Reproduction of Vertebrates. Volume 3: Reptiles. New York, Academic Press, 2011.

Novelli, I. A.; De Oliveira, P. R.; Christina, M. C. M. N.; Silva, P. C. \& De Sousa, B. M. Morphological and histological characterization of sexual segment of the kidney in Notomabuya frenata (Cope, 1862) and Aspronema dorsivittatum (Cope, 1862) (Squamata, Mabuyidae). An. Acad. Bras. Cienc., 90(2 Suppl. 1):2267-78, 2018.

O’Malley, B. Lizards. In: O'Malley, B (Ed.). Clinical Anatomy and Physiology of Exotic Species. Philadelphia, Elsevier/Saunders, 2005. pp.57-76.

Pfeifer, M. Veiled chameleon (Chamaeleo calyptratus) close-up. In: Texas A\&M Veterinary Medical Diagnostic Laboratory, 2019. Available from: https://tvmdl.tamu.edu/2019/01/15/isolation-of-nannizziopsis-sp-fromskin-lesions-of-a-veiled-chameleon-chamaeleo-calyptratus/veiledchameleon-chamaeleo-calyptratus-close-up/

Prasad, M. R. N. \& Reddy, P. R. K. Physiology of the sexual segment of the kidney in reptiles. Gen. Comp. Endocrinol., 3 Suppl.:649-62, 1972.

Reavill, D. R. \& Schmidt, R. E. Urinary tract diseases of reptiles. J. Exot. Pet Med., 19(4):280-9, 2010.

Regaud, C. \& Policard, A. Variations sexuelles de structure dans le segment préterminal du tube urinifère de quelques ophidiens. C. R. Soc. Biol., 55:216-8, 1903 . 
AL-SHEHRI, M. A. \& AL-DOAISS, A. A. A morphological, histological, and histochemical study of the sexual segment of the kidneyof the male Chamaeleo calyptratus (veiled chameleon). Int. J. Morphol., 39(4):1200-1211, 2021

Rheubert, J. L.; Murray, C. M.; Siegel, D. S.; Babin, J. \& Sever, D. M. The sexual segment of Hemidactylus turcicus and the evolution of sexual segment location in squamata. J. Morphol., 272(7):802-13, 2011.

Rheubert, J. L.; Sever, D. M.; Siegel, D. S. \& Trauth, S. E. Male Reproductive Anatomy: The Gonadoducts, Sexual Segment of the Kidney and Cloaca. In: Rheubert, J. L.; Siegel, D. S. \& Trauth, S. E. (Eds.). Reproductive Biology and Phylogeny of Lizards and Tuatara. Boca Raton, CRC Press, Taylor \& Francis Group, 2014. pp.253-301.

Sanyal, M. \& Prasad, M. Sexual segment of the kidney of the Indian house lizard, Hemidactylus flaviviridis Rüppell. J. Morphol., 118:511-27, 1966.

Schimming, B. C. \& Vicentini, C. A. Histochemical study in the epidermis of the dog (Canis familiaris). Rev. Chil. Anat., 18(1):123-32, 2000.

Sever, D. M. \& Hopkins, W. A. Renal sexual segment of the ground skink, Scincella laterale (Reptilia, Squamata, Scincidae). J. Morphol., 266:4659, 2005.

Sever, D. M.; Rheubert, J. L.; Gautreaux, J.; Hill, T. G. \& Freeborn, L. R. Observations on the sexual segment of the kidney of snakes with emphasis on ultrastructure in the yellow-bellied sea snake, Pelamis platurus. Anat. Rec. (Hoboken), 295(5):872-85, 2012.

Suvarna, K. S.; Layton, C. \& Bancroft, J. D. Bancroft's Theory and Practice of Histological Techniques. London, Elsevier, 2019.

Uetz, P. \& Hosek, J. The Reptile Database. Website, 2017. Available from: http://www.reptile-database.org

Zwart, P. Renal pathology in reptiles. Vet. Clin. North Am. Exot. Anim. Pract., 9:129-59, 2006.

Zwart, P. Studies on renal pathology in reptiles. Vet. Pathol., 1(6):542-56, 1964.

\section{Corresponding author: \\ Amin Abdullah Al-Doaiss \\ Department of Biology \\ College of Science \\ King Khalid University \\ P.O.Box: 9004 \\ Postal Code: 61413 Abha \\ SAUDI ARABIA}

\section{E-mail: aaldoaiss@kku.edu.sa amindos75@yahoo.com}

Received: 25-04-2021

Accepted: 30-05-2021 